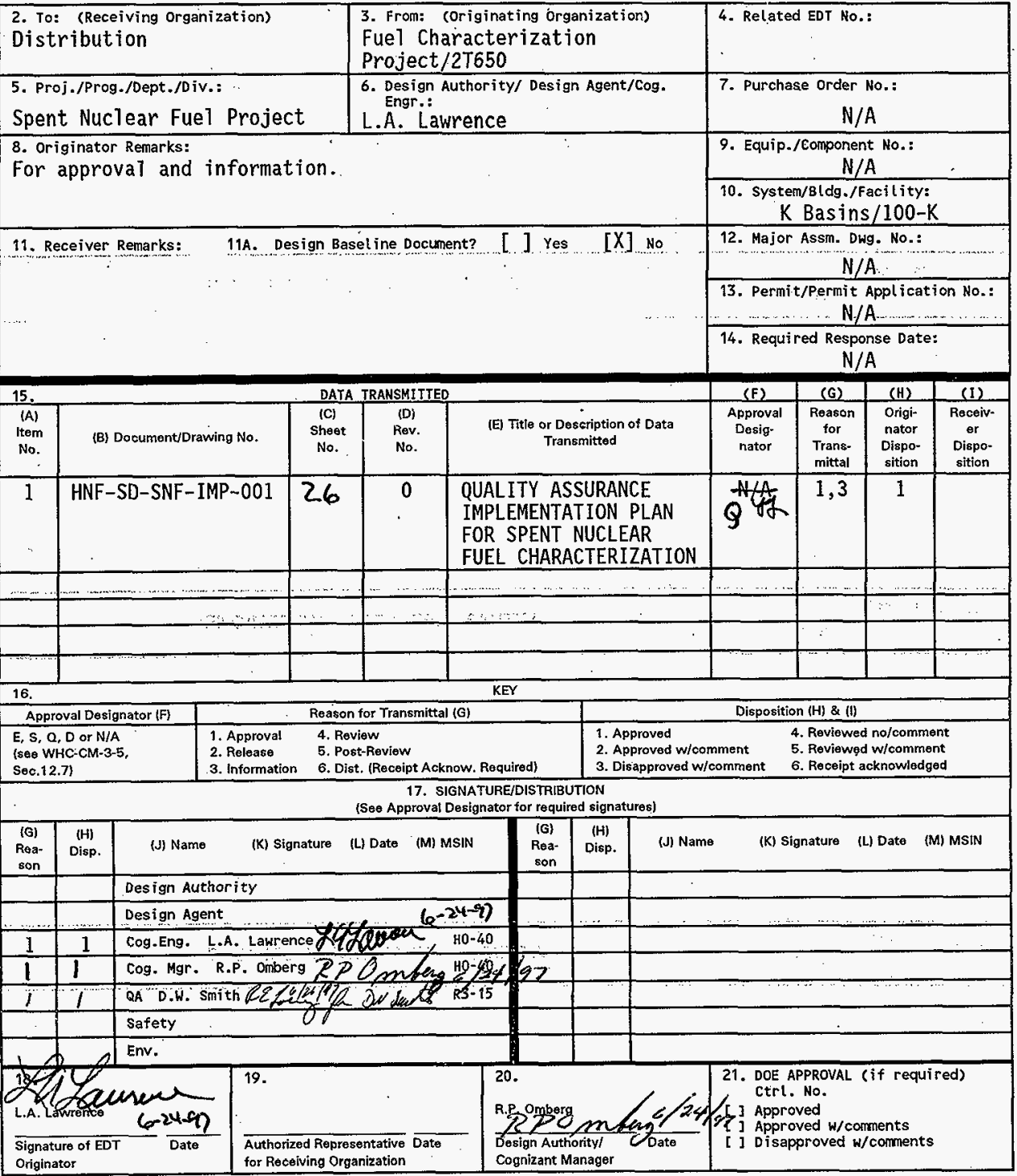




\section{QUALITY ASSURANCE IMPLEMENTATION PLAN FOR SPENT NUCLEAR FUEL CHARACTERIZATION}

\section{J. Horhota}

DE\&S Northwest, Inc., Richland, WA 99352

\section{A. Lawrence}

DE\&S Hanford, Inc., Richland, WA 99352

U.S. Department of Energy Contract DE-AC06-96RL13200

EDT/ECN: 620791

Org Code: $2 T 650$

B\&R Code: EW7040000
UC: 2070

Charge Code: E70189

Tota1 Pages: 26

Key Words: Quality Assurance, Spent Nuclear Fue1, 105-K Basins, Implementation Plan

Abstract: A plan was prepared to implement the Quality Assurance requirements of the Office of Civilian Radioactive Waste Management RW-0333P to the Spent Nuclear Fuel Characterization activities. The plan was based on an evaluation of the current characterization activities against the $\mathrm{RW}-0333 \mathrm{P}$ requirements.

TRADEMARK DISCLAIMER. Reference herein to any specific commercial product, process, or service by trade name, trademark, manufacturer, or otherwise, does not necessarily constitute or imply its endorsement, recommendation, or favoring by the United States Government or any agency thereof or its contractors or subcontractors.

Printed in the United States of America. To obtain copies of this document, contact: Document Control Services, P.0. Box 950, Mailstop H6-08, Richland WA 99352, Phone (509) 372-2420; Fax (509) 376-4989.
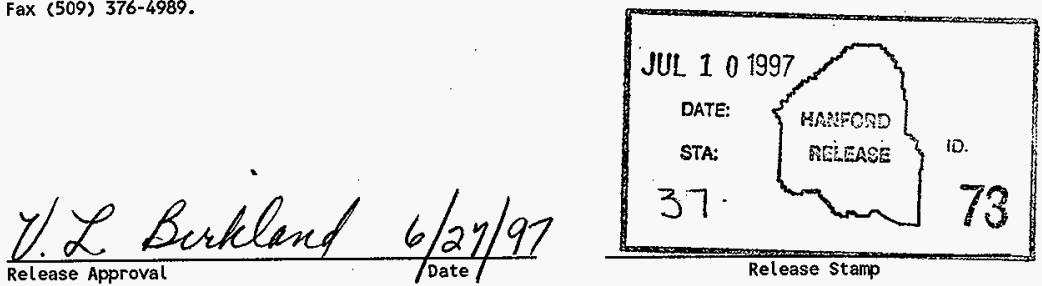
HNF-SD-SNF-IMP-001, Rev. 0

QUALITY ASSURANCE IMPLEMENTATION PLAN FOR SPENT NUCLEAR FUEL CHARACTERIZATION

M. J. Horhota

DE\&S Northwest, Inc.

L. A. Lawrence

DE\&S Hanford, Inc.

June 1997 
Document Tit]e:

Prepared by:

Prepared by:

Approved by:

Approved by:

Approved by:
QUALITY ASSURANCE IMPLEMENTATION PLAN FOR SPENT NUCLEAR FUEL CHARACTERIZATION

M.

M. J. Aorhota

Quality Assurance

DE\&S Northwest, Inc.

$\frac{6-24-27}{\text { Date }}$

$\frac{6-24-97}{\text { Date }}$

Fuel Characterization Project

DE\&S Hanford, Inc.

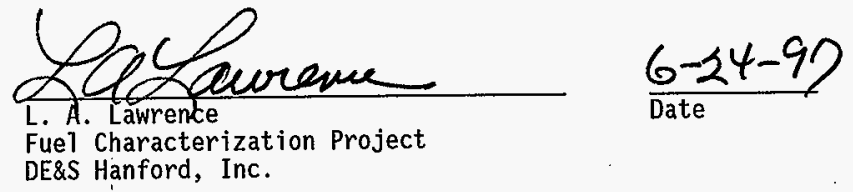

$\frac{\text { TPO mferg }}{\text { R. P. Omberg, Managep }}$ Fuel Characterization Project DE\&S Hanford, Inc.

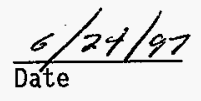
Qual ity Assurance DE\&S Hanford, Inc.

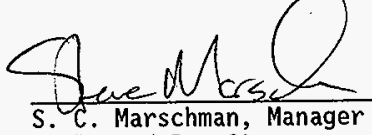

$$
\frac{6-24-97}{\text { Date }}
$$

Fuels and Dry Storage

Pacific Northwest National Laboratory Spent Nuclear Fuels Project 
HNF-SD-SNF-IMP-001, Rev. 0

This page intentionally left blank. 
HNF-SD-SNF-IMP-001, Rev. 0

\section{EXECUTIVE SUMMARY}

A plan was prepared to implement the Quality Assurance requirements of the Office of Civilian Radioactive Waste Management RW-0333P to the Spent Nuclear Fuels Characterization activities. The plan was based on an evaluation of the current characterization activities against the RW-0333P requirements. 
HNF-SD-SNF-IMP-001, Rev. 0

This page intentionally left blank. 
HNF-SD-SNF-IMP-001, Rev. 0

\section{CONTENTS}

1.0 INTRODUCTION ................................. 6

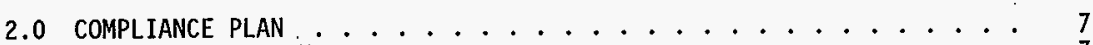

2.1 ORGANIZATION $\ldots \ldots \ldots 7$

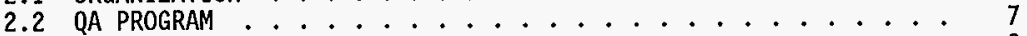

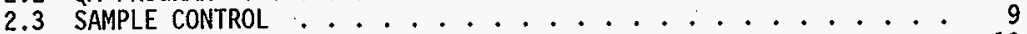

2.4 SCIENTIFIC INVESTIGATION $\ldots \ldots \ldots \ldots$

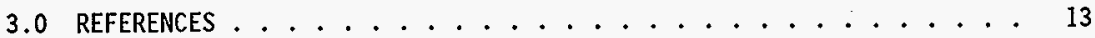

APPENDIX A RESULTS OF OCRWM 0333P EVALUATION ON SPENT NUCLEAR

FUEL PROJECT CHARACTERIZATION ......... 15 
HNF-SD-SNF-IMP-001, Rev. 0

\section{QUALITY ASSURANCE IMPLEMENTATION PLAN FOR SPENT NUCLEAR FUEL CHARACTERIZATION}

\subsection{INTRODUCTION}

A baseline evaluation of the Spent Nuclear Fuel Project (SNFP) Characterization Activities was conducted by DE\&S Northwest against the requirements of the Office of Civilian Radioactive Waste Management (OCRWM) RW-0333P, Quality Assurance Requirements and Description (QARD) document (DOE 1995).

The evaluation was conducted during May 1997 and it focused on the Quality Assurance (QA) management processes described in the Fluor Daniel Hanford (FDH) QA manual CM-4-2 (WHC 1995) and the SNFP QA Program PIan (SNFP 1997) and how well these processes satisfied the requirements found in the QCRWM QARD. The review concentrated on reviewing those Project Hanford site wide procedures and facility level administrative procedures that are used by SNFP Characterization to implement fuel characterization sampling and data collection activities within the basin. The project's " $Q$ 1ist" document (Lacey 1997) was the basis used to determine which of SNFP Characterization activities fell under the scope of the OCRWM QA program. The results of the evaluation are listed on Attachment $A$ categorized under the eighteen elements and five supplements found in the OCRWM QARD. Issues that are marked with a "*" are considered to be unique to the characterization sub-project and corrective action will be initiated at that level. The remaining issues are considered to have project-wide impact and corrective action may be more effective if it was initiated at the project level. 


\subsection{COMPLiance PLAN}

The plan to comply with the QARD RW-0333P is divided into the following four topics which address the findings in the evaluation (Appendix $A$ ): organization, QA plan, sample control, and scientific investigations. The findings and the corrective actions identified are summarized in the following sections.

\subsection{ORGANIZATION}

The SNFP Characterization has no organizational chart that identifies the key positions and responsibilities within the organization for achieving quality (Section 1.2.1).*

\section{Proposed Corrective Actions:}

A. Develop a SNFP characterization organizational chart and a listing of key responsibilities.
Responsibility:
L. A. Lawrence
ECD : ** 10-31-97

B. Issue and approve the organizational chart and responsibilities list as part of the SNFPs Characterization Program Management P1 an WHC-SD-SNF-PLN-010 (Lawrence 1995).

Responsibility: L. A. Lawrence

ECD: $\quad 12-31-97$

\subsection{QA PROGRAM}

The SNFP Characterization does not have a written policy/practice on how they will apply QA controls in a graded approach when collecting SNF characterization data. Current7y, WHC-SD-SNF-RPT-007 does not provide for one. The SNFP may want to review this practice and decide if a graded approach should be developed (Section 2.2.4C).

Proposed Corrective Actions:

Since all of SNFP Characterization data collection activities are controlled by established procedures the amount of documentation being generated for each sampling campaign does not vary. (The description of

\footnotetext{
*Refers to the identified section of the QARD. $\star * E C D=$ Estimated Completion Date.
} 
the process and documents generated will be addressed under the corrective action for Section 2.4, Item 2.) The only variability lays with the amount of $\mathrm{QC}$ samples and independent data verification done.

A. Determine what types of QC controls (e.g., QC samples, data reviews, level of data validation, etc.) are required and incorporate them into the SNFP Characterization Program Management P1an WHC-SD-SNF-PLN-010 (Lawrence 1995).

Responsibility: M. J. Horhota ECD: 12-31-97

The SNFP Characterization has defined the following fuel characterization activities as OCRWM related:

- Physical Condition

- Hydride and Oxide Content

- Ignition Testing

- Oxidation Kinetics

- Fuet Drying Studies

Some sludge is expected to be trapped within the fuel elements on the surfaces following fuel retrieval and cleaning. This material will accompany the fuel in the Multi-Canister Overpack (MCO). Consequently, this material is defined to be OCRWM related. Sludge identified in this plan to fall within the OCRWM requirements relates to this material and not sludge that has been removed from the basins for characterization to support the path forward for that material.

The SNFP characterizations needs to decide what testing programs are developing data that feed these various activities and what characteristics are critical data inputs that fall under OCRWM QA program. Otherwise as this requirement is now written all data for these fuel activities will have to be controlled by OCRWM.

Guidance that may prove helpful in identifying these critical data needs and developing this flowchart can be found in the draft Guidel ines for Meeting Repository Requirements for Disposal of DOE SNF document (INEL 1997).

\section{Proposed Corrective Actions:}

A. Develop an OCRWM flow chart that defines what critical characteristics of the SNF characterization test program fall under OCRWM QARD.

$\begin{array}{ll}\text { Responsibility: L. A. Lawrence ECD: 12-3I-97 } & \text { L. }\end{array}$

B. Incorporate this list of critical characteristics into WHC-SD-SNF-RPT-007 (Lacey 1997).

Responsibility: L. A. Lawrence ECD: 04-30-98

The SNFPs Characterization Program Management Plan WHC-SD-SNF-PLN-010 does not contain all the planning elements required to satisfy the QARD requirements for work planning (Section 2.2.5). 
-HNF-SD-SNF-IMP-001, Rev. 0

\section{Proposed Corrective Actions:}

A. Revise SNFPs Characterization Program Management Plan WHC-SD-SNF-PLN-010 to include the following topics:

- Define work scope through the 1isting of the primary tasks and the deliverables required for each task,

- Identify the technical approach and implementing procedures that will be used to collect, analyze and evaluate the results

- Identify any applicable technical standards or criteria that will be used to guide the study.

- Identify field and laboratory equipment that will be used.

- Identify the records that will be generated.

- Identify required QA inspections, special controls or computer software required.

Responsibility: L. A. Lawrence ECD: 10-31-97

B. Issue and approve the revised Characterization Program Management P1 an WHC-SD-SNF-PLN-010.

$\begin{array}{lll}\text { Responsibility: L. A. Lawrence ECD: 12-31-97 } & \text { LCE }\end{array}$

The SNFP Characterization has not performed any documented management assessments on its own activities (Section 2.2.7).

\section{Proposed Corrective Actions:}

A. Establish an assessment schedule as required by DE\&SH management directive DESH-MD-002 (Hudson 1997).

$\begin{array}{ll}\text { Responsibility: R. P. Omberg } & \text { ECD: 12-31-97 }\end{array}$

B. Perform first management assessment of SNFP Characterization activities in accordance with DE\&S Hanford management directive DESH-MD-002.

$\begin{array}{ll}\text { Responsibility: R. P. Omberg ECD: 04-30-98 } & \text {. }\end{array}$

\subsection{SAMPLE CONTROL}

The SNFP Characterization has not defined how the SNF samples will be identified, tracked or controlled. In practice, SNFP is using sample numbers, that are traceable back to the fuel elements in the pool to provide 
traceability and these numbers get documented in the MWP. Further control is provided through chain of custody forms, SNM accountability procedures and fuel sectioning plans (used to subdivide the fuel samples for individual testing). So SNFP is controlling the sample and satisfying this requirement. However, this process needs to be documented (Supplement II.2.1B).

\section{Proposed Corrective Actions:}

A. Prepare a section in the SNFP Characterization Management PIan and a procedure that describes how SNFP Characterization will identify, track and control SNF/STudge samples.

Responsibility: L. A. Lawrence/R. B. Baker ECD: 10-31-97

B. Issue and approve the revised SNFP Characterization Management PIan WHC-SD-SNF-PLN-010.

Responsibility: L. A. Lawrence ECD: 12-31-97

The SNFP Characterization has not defined the process by which they will identify and evaluate nonconforming samples. In accordance with SNFPs QAPP this should be done through the NCR process. However, the criteria for using QI $15,1 / 2$ to document nonconforming samples and data is less than adequate. Therefore, SNFP Characterization should develop such criteria and document it (Supplement II.2.7).

\section{Proposed Corrective Actions:}

A. Prepare a section in the SNFP Characterization Management P1 an and a procedure if necessary that describes how SNFP Characterization will control nonconforming samples.

Responsibility: M. J. Horhota ECD: 10-31-97

B. Issue and approve the revised SNFP Characterization Management PIan WHC-SD-SNF-PLN-010.

Responsibility: L. A. Lawrence $\quad$ ECD: $12-31-97$

\subsection{SCIENTIFIC INVESTIGATION}

The SNFP Characterization has not defined the process by which they will plan and conduct scientific investigations. In practice, SNFP is using the test control process in CM-6-1 to control these activities (WHC 1996). Typically, SNFP plans the sampling campaign using a Data Quality Objectives (DQO) document, which generates a Sample Analysis Plan which defines the samples to be collected. The actual sampling function is controlled through Job Control System (JCS) work packages and documented on the K Basin Master Work Plan (MWP). Analytical testing is conducted by others and documented through analytical test packages. Evaluation of the data usability is done by SNF Characterization through a Final Test Report. So SNFP is controlling scientific investigation, however, the process is not documented (Supplement III.2.1A). 
Since scientific investigation activities are not just confined to the fuel characterization sub-project, it is recommended that SNFP management evaluate this issue for project wide impact and determine if it may be more effective to issue a project wide procedure for controlling scientific investigations.

Proposed Corrective Actions

A. Prepare an section for the SNFP Characterization Management Plan that describes how SNFP Characterization controls scientific investigations.

Responsibility: M. J. Horhota ECD: 10-31-97

B. Issue and approve the revised SNFP Characterization Management P1an WHC-SD-SNF-PLN-010.

$\begin{array}{ll}\text { Responsibility: L. A. Lawrence ECD: 12-31-97 } & \text { La }\end{array}$

The SNFP Characterization has not taken steps to update their original DQO documents since they have been developed. Instead they use weekTy planning meetings to decide which direction to proceed with the investigation. This has resulted in a process where the study has deviated from the original objectives called out by the DQOS and there is not a well established documentation pathway that shows what changes were made and why they were made. Typically, DQOs are used to determine data usability and since they have been not maintained, validating the data and justifying the conclusions being drawn may be difficult (Supplement III.2.1A).

\section{Proposed Corrective Actions:}

Instead of trying to go back and revised the original DQOs documents, SNFP Characterization management has determined it would be more cost effective to wait until the final test report for each sludge and fuel sampling campaign is issued to reconcile the test objectives called out in the DQOS against the data collected and justify any deviations between the two.

A. Develop a schedule on preparing final test reports for sludge and fuel samples.

Responsibility: L. A. Lawrence ECD: 10-31-97

B. Issue the schedule as part of the revised SNFP Characterization Program Management PI an WHC-SD-SNF-PLN-010.

$\begin{array}{ll}\text { Responsibility: L. A. Lawrence } & \text { ECD: } 12-31-97\end{array}$ 
HNF-SD-SNF-IMP-001, Rev. 0

This page intentionally left blank. 


$$
\text { HNF-SD-SNF-IMP-001, Rev. } 0
$$

\subsection{REFERENCES}

DOE, 1995, "Quality Assurance Requirements and Description DOE/RW/0333P," Revision 5, Office of Civilian Radioactive Waste Management, U.S. Department of Energy, Washington, D.C.

INEL, 1997, "Guidelines for Meeting Repository Requirements for Disposal of U.S. Department of Energy Spent Nuclear Fue l (Draft), " DOE/SNF/REP-009, Idaho, National Laboratory, Idaho.

Hudson, F. G., 1997, Letter to N. H. Williams, Project Director Spent Nuclear Fuel Project, "DE\&S Hanford, Inc., Management Assessment Procedure," DESH-9753118 Rl, dated may 15, 1997, Duke Engineering and Services Hanford, Inc., Richland, Washington.

Lacey, R. E., 1997, Application of the Office of Civilian Radioactive Waste Management Quality Assurance Requirements to the Hanford Spent Nuclear Fuel Project, WHC-SD-SNF-RPT-007, Rev. 0, Westinghouse Hanford Company, Richland, Washington.

Lawrence, L. A., 1995, Characterization Program Management Plan for Hanford $K$ Basin Spent Nuclear Fue], WHC-SD-SNF-PLN-010, Rev. 0, Westinghouse Hanford Company, Richland, Washington.

Lawrence, L. A., K. S. Redus, and T. A. Thornton, 1994, Spent Nuclear Fuels Project Characterization Data Qua7ity Objectives Strategy, WHC-EP-0795, Westinghouse Hanford Company, Richland, Washington.

SNFP, 1997, Spent Nuclear Fue7 Project Qua7ity Assurance Program P7an, HNF-SD-SNF-QAPP-004, Rev. 1, Spent Nuclear Fuel Project Division, U.S. Department of Energy, Richland Operations Office, Richland, Washington.

WHC, 1996, Standard Engineering Practices, WHC-CM-6-1, Re1ease 70, Westinghouse Hanford Company, Richland, Washington.

WHC, 1995, Quality Assurance Manua7, WHC-CM-4-2, Westinghouse Hanford Company, Richland, Washington. 
HNF-SD-SNF-IMP-001, Rev. 0

This page intentionally left blank. 
HNF-SD-SNF-IMP-001, Rev. 0

\section{APPENDIX A}

\section{RESULTS OF OCRWM O333P EVALUATION ON SPENT NUCLEAR FUEL PROJECT CHARACTERIZATION}

\section{ORGANIZATION}

*1. The SNFP Characterization has no organizational chart or identifies the key positions and responsibilities within the organization for achieving quality (Section 1.2.1).

2. The SNFP has no policy on having the QA manager's position being the same or a higher management level position than the highest line managers position (Section 1.2.2A).

Note: In practice SNFP complies with this requirement since the QA Manager reporting directly to the Vice President \& Project Director. However, all other direct support positions are titled Deputy Project Directors.

\section{QA PROGRAM}

3. The SNFP shall have a structured system that shows the implementing documents that provides evidence that the requirements of the OCRWM are being properly implemented and develop a requirements matrix (Sections 2.2.1B1,2,3 and 2.2.1C).

Note: The SNFP QA is in the process of developing a QARD requirements Matrix. Once it is complete it should satisfy this requirement.

4. The SNFP shall review revisions of the QARD and incorporate changes into their implementing procedure, as appropriate. Since no matrix exists at this time, this review can not take place (Section 2.2.1B4).

*5. The SNFP Characterization does not have a written policy/practice on how they will apply QA controls in a graded approach when collecting SNF characterization data. Currentiy, WHC-SD-SNF-RPT-007 does not provide for one. SNFP may want to review this practice and decide if a graded approach should be developed (Section 2.2.4C).

6. The SNFP does not have a written policy/practice on how they will apply QA controls in a graded approach that satisfies the intent of the OCRWM QARD requirements in Section 2.2.4E through $\mathrm{J}$ (Section 2.2.4). 
*7. The SNFP Characterization has defined the following fuel characterization activities as OCRWM related:

- Physical Condition

- Hydride and oxide Content.

- Ignition Testing

- Oxidation Kinetics

The SNFP characterizations needs to decide what testing programs are developing data that feed these various activities and what characteristics are critical data inputs that fall under OCRWM QA program. Otherwise as this requirement is now written all data for these fuel activities will have to be controlled by OCRWM.

Note: Guidance that may prove helpful in identifying these critical data needs and developing this flowchart can be found in the draft Guidelines for Meeting Repository Requirements for Disposal of DDE SNF document (DOE/SNF/REP-009)

*8. The SNFPs Characterization Program Management Plan (WHC-SD-SNF-PLN-010) does not contain a11 the planning elements required to satisfy the QARD requirements for work planning (Section 2.2.5).

9. The SNFP QA has not performed any surveitlances on SNFP Characterization activities Section 2.2.6.

*10. The SNFP Characterization has not performed any documented management assessments on its own activities Section 2.2.7.

11. The SNFP has no proceduralized system that defines how it will perform peer reviews Section 2.2.9.

Note: At the time of this assessment SNFP was in the process of issuing a SNFP administrative procedure on peer reviews (96-009-00). A review of the draft procedure against the OCRWM QARD revealed the following weaknesses in the draft procedure:

(a) Scope: the procedure applies oniy to the SNF Project Technical Databook and to information that is used in the SARP or SAR. The scope should be expanded to include all of the SNFP activities.

(b) The procedure is written to be consistent with the design verification procedure (EP 4.1 ) found in $C M-6-1$ manual. The procedure seems to focuses on having one or more reviewers evaluate the document in isolation and document their individual issues on RCRs. However, the OCRWM QARD intent is to have a formal review team established and the Team Chairman must issue a formal report at the completion of the team's activities. 
12. The SNFPs document review process does not specifically address the OCWRM QARD requirements for reviewers to be technically competent in the subject area being reviewed or that the scope of the reviews must cover all aspects of the document. However, various sections of the CM-3-5 manual does seem to imply the need for these requirements to be satisfied (Section 2.2:10D and $E$ ).

13. The SNFPs document review process does not require each reviewing organization to have established review criteria available when they review documents. Instead, the process relies heavily on the experience and knowledge of the reviewer in order for the process to be effective (Section 2.2.10E1).

14. The SNFP QA shall review implementing documents that translate the QARD requirements into work processes. Since there currently is no matrix that defines what these documents are there is no assurance SNFP QA can show compliance with this requirement Section 2.2.10E2.

15. The SNFP management shall be appraised as to the adequacy and compliance aspects of the QA program. Currently, SNFP is doing that informally through weekly reports and presentations at managers/ DOE-RL meetings and in practice, senior project management are aware of significant QA issues. Also, affected line management are on distribution for surveillance reports, FEB assessments, HATS trending reports, etc., and that may meet the intent of this requirement. However, SNFP may still want to review these practices and decide if a more formalized reporting process would be more effective (Section 2.2.11).

16. The SNFP Characterization training focuses on training required to gain facility access and is somewhat weak on job position training and specific training required to maintain job proficiency (Section 2.2.12C). Though there are some institutionalized site training programs that are task oriented (e.g., hot cell worker, radiation worker, hazardous waste worker, etc.) these are centered around generic job classifications around the site and only partially satisfy the QARD. Other portions of the training program that do not satisfy the QARDS standards are:

- Evaluation the job position to determine if the work is subject to the QARD (Section 2.2.12B).

- Training to the QARD itself (Section 2.2.12J1).

Note: This issue may not be confined to just the fuel characterization sub-project it is recommended that SNFP management evaluate this issue for project wide impacts and determine if corrective action should be taken at the project level. 


\section{DESIGN CONTROL}

17. The SNFP relies on CM-6-1 manual to achieve compliance with the QARD design control requirements. However, $\mathrm{CM}-6-1$ has a guidance document (IP-1026) that supplements the CM manual and takes QA requirements (e.g., Appendixes on engineering document's content and format) and makes them optional. This practice is not in compliance with the QARD.

18. The EP1.11 only requires computer software used to perform design analyses to be verified to assure it produces correct solutions and models the problem correctly. This would not comply with the QARD requirements for software QA under Supplement I (Section 3.2.3D).

19. The EP 4.1 does not require the selection of the design verification method to be justified (Section 3.2.4B).

20. The OCRWM QARD requires that the designated approving organization shall have demonstrated competence in the design area of interest and have an adequate understanding of the original design intent. Also if they differ from the original design organization they have been properiy designated .to carry out that function. Neither CM-4-2 or CM-6-1 address this as policy or provide for an implementing procedure (Section 3.2.8C1 and 2).

\section{PROCUREMENT DOCUNENT CONTROL}

No issues identified.

\section{IMPLEMENTING DOCUMENTS}

Currently SNFP Characterization has not developed any implementing documents of their own. Instead they use the procedures defined in the various site wide control manuals to control their work activities. Since these procedures are mostiy administrative in nature much of the information required by QARD Section 5.2.2 would not be applicable. Only one issue regarding the site wide CM procedures in relationship with the QARD requirements was identified.

The current $\mathrm{CM}$ format as called out in $\mathrm{CM}-3-6$, Section 2.6 does not require the identification of 1 ifetime/nonpermanent records generated by the procedure as required by QARD, Section 5.2.2H. However, FDH is proposing a new procedural system that will require records to be identified in each of the new PHMC wide procedures. Once this new system is in place the site wide procedures should better match the OCRWM requirements. 


\section{DOCUMENT CONTROL}

No issues identified.

\section{CONTROL OF PURCHASED ITEMS AND SERVICES}

No issues identified.

\section{IDENTIFICATION AND CONTROL OF ITEMS}

This section is not applicable for SNFP Characterization since they only work with samples and data processing. See Supplement II for requirements on sample identification.

\section{CONTROL OF SPECIAL PROCESSES}

This section is not applicable to SNFP Characterizations since they are only collecting data and are not involved in the fabrication of safety related hardware.

\section{INSPECTION}

No issues identified.

\section{TEST CONTROL}

21. Test report format and content are covered by IP-1026 the engineering guidance document. Some of the QA requirements required by OCRWM (Sections 11.2 .1 and 11.2.5) are found in the IP and therefore are optional. This practice is not in compliance with the QARD.

22. The EP-4.2 does not require the test status of an item to be identified in accordance with the requirements of NQA-1 Criteria 14Inspection, Test and Operating Status (Section 11.2.4B).

23. The SNFP testing personnel are not qualified to similar criteria used for $Q A$ inspection personnel. See Section 10.2.9 of the OCRWM QARD for details (Section 11.2.6).

\section{CONTROL OF METE}

24. The $Q R 12.0$ does not address M\&TE with programmable software, the need to control the software through $Q R$ 19.0 or recalibrate the instrument when the software changes (Sections 12.2.1A and 12.2.1G). 
25. The OCRWM QARD requires caljbration standards to comply with the following:

- Calibration standards shall have a greater accuracy than the required accuracy of the M\&TE being calibrated.

- If standards with greater accuracy do not exist, standards with equal accuracy to the required calibration may be used, if it can be shown they are adequate to maintain the instruments in tolerance.

- The basis for the calibration acceptance shall be documented and approved. The level of management authorized to provide this approval shall be documented (Section 12.2.1B).

The QR 12.0, Section 3.4, does not go into the level of detai1 required by the QARD. However, the calibration standards internal procedures (WHC-SP-0446) does require standards to have a 4 to 1 ratio accuracy over the M\&TE being calibrated. However, if that is not possible the basis for using a less accurate standard shall be documented. However, the level of management responsible for performing this function are not identified.

26. The QR 12 does not address how to control M\&TE used for one time applications (Section 12.2.1C).

27. The QR 12 does not require when, where and how the M\&TE instrument was used to be documented. However, in practice implementing procedures for JCS, test $\mathrm{pl}$ ans and other work control documents do require M\&TE usage to be recorded. So SNFP is meeting the intent of this requirement, but we have no written policy that says it (Section 12.2.2).

28. The QR 12 does not address how to control M\&TE that is lost before it can be recalibrated and the data collected with the instrument is indeterminate (Section 12.2.4).

\section{HANDLING, STORAGE, AND SHIPPING}

The only special handing that SNFP Characterization is performing related to the fuel samples is using a Chain of Custody form to document sample possession. All other portions of this section are not applicable to SNFP Characterization.

29. The SNFP Characterization is using the COC/SAR form that comes out of EII 5.1 in CM-7-7. However, CM-7-7 is a Level III manual that is not for use by SNFP. Therefore, SNFP currently does not have an approved procedure to cover this activity (Section 13.2.1). 
Since the $C O C$ form is used for both environmental and fuel/sludge sampling activities, it is recommended that SNFP management evaluate this issue for project wide impact and determine if it may be more effective to issue a project wide procedure for both functions.

\section{INSPECTION, TEST, AND OPERATING STATUS}

This section not evaluated; $\mathrm{K}$ Basins and SNFP does not use status tags; al1 inspections and tests are traceable to the item/sample through work packages/test plans/etc.

\section{NONCONFORMANCES}

This section not evaluated; SNFP Characterization has not issued any NCRs on the fuel characterization data at this time. However one issue related to controlling nonconforming data was identified. See Supplement II, Section 2.7 for details.

\section{CORRECTIVE ACTION}

30. The QARD requires adverse conditions to be classified as either (1) conditions adverse to Quality or (2) significant conditions adverse to quality. However, the CM-4-1 uses the PPG system to classify and grade corrective action taken. This approach needs to be justified and documented (Sections 16.2.2 and 16.2.4A).

31. The QARD requires conditions that are adverse to quality to be tracked by the QA organization. However, per Q1 16.1, this is a Tine organization function and not done by QA (Sections 16.2.3A and 16.2.4B).

32. The $Q A R D$ requires $Q A$ to concur with proposed remedial actions/ corrective actions. However, QR 16.0, Section 4.2 .2 only requires that concurrence on $Q A$ initiated items (Sections 16.2.3C and 16.2.4F).

33. The QARD requires the QA organization to verify implementation of corrective actions taken on all conditions adverse to quality and close the corrective action documentation. However, $\mathrm{CM}-1-4$, Section 1.0, Figure 1 only requires the oversight organization to do this function on a sampling basis when the adverse condition has a PPG value of over 25 (Section 16.2.5).

34. The SNFP does not have a trending procedure as required by QI 16.1 to implement the requirements in the QARD (Section 16.2.6). 
HNF-SD-SNF-IMP-001, Rev. 0

\section{QA RECORDS}

35. The QARD requires $Q A$ records to be classified as either (1) lifetime or (2) nonpermanent. However, the QR 17 does not $\mathrm{classify}$ records in this manner instead it follows the National Archives requirements for dispositioning federal records. The SNFP needs to evaluate this approach and determine if meets the intent of QCRWM (Section 17.2.1).

36. The SNFP does not have procedures in place to address how they will replace, restore or substitute damaged or lost QA records.

\section{AUDITS}

This section not evaluated; this is outside the scope of SNFPs work, FDH, IPA, and FEB organizations perform this function.

\section{SUPPLEMENT I (SOFTWARE)}

This section not evaluated; SNFP Characterization is not developing, modifying or using any software as part of the fuel characterization study.

\section{SUPPLEMENT II (SAMPLE CONTROL)}

*37. The SNFP Characterization has not defined how the SNF samples will be identified, tracked or controlled. In practice, SNFP is using sample numbers, that are traceable back to the fuel elements in the pool to provide traceability and these numbers get documented in the MWP. Further control is provided through chain of custody forms, SNM accountability procedures and fuel sectioning plans (used to subdivide the fuel samples for individual testing). So, SNFP is controlling the sample and satisfying this requirement. However, this process needs to be documented (Supplement II.2.1B).

*38. The SNFP Characterization has not defined the process by which they will identify and evaluate nonconforming samples. In accordance with SNFPS QAPP this should be done through the NCR process. However, the criteria for using QI $15.1 / 2$ to document nonconforming samples and data is less than adequate. Therefore, SNFP Characterization should develop such criteria and document it (Supplement II.2.7).

\section{SUPPLEMENT III (SCIENTIFIC INVESTIGATION)}

39. The SNFP Characterization has not defined the process by which they will $\mathrm{pl}$ an and conduct scientific investigations. In practice, SNFP is using the test control process in $\mathrm{CM}-6-1$ to control there 
activities. Typically, SNFP plans the sampling campaign using a DQO document, which generates a Sample Analysis Plan which defines the samples to be collected. The actual sampling function is controlled through JCS work packages and documented on the K Basin MWP. Analytical testing is conducted by others and documented through analytical test packages. Evaluation of data usability is done by SNF Characterization through a Final Test Report. So, SNFP is controlling scientific investigation, however, the process is not documented (Supplement III.2.1A).

Note: Since scientific investigation activities are not just confined to the fuel characterization sub-project, it is recommended that SNFP management evaluate this issue for project wide impact and determine if it may be more effective to issue a project wide procedure for controlling scientific investigations.

*40. The SNFP Characterization has not taken steps to update their original DQO documents since they have been developed. Instead they use weekly planning meetings to decide which direction to proceed with the investigation. This has resulted in a process where the study has deviated from the original objectives called out by the DQOS and there is not a well established documentation pathway that shows what changes were made and why they were made. Typically, DQOS are used to determine data usability and since they have been not maintained, validating the data and justifying the conclusions being drawn may be difficult (Supplement III.2.1A).

41. The SNFP Characterization has no established procedure on how to control scientific notebooks. The $K$ Basins does have a procedure in place AP-2-018-03 that addresses logkeeping. However, it only covers operations and radiological logbooks (Supplement III.2.2).

Note: Since notebooks were only used during the testing of the sampling equipment the data contained in them would not fall under the OCRWM scope of work. However, SNFP management should evaluate this issue for project wide impacts and determine if there is a need to develop a project level procedure to control scientific notebooks.

42. The SNFP Characterization has not defined the process that they use to identify data so it is traceable to its associated documentation or qualification status (Supplement III.2.3).

Note: This issue may not be confined to just the fuel characterization sub-project it is recommended that SNFP management evaluate this issue for project wide impacts and determine if corrective action should be taken at the project level. 
HNF-SD-SNF-IMP-001, Rev. 0

43. The SNFP Characterization has not defined the process by which they will control unqualified data and the methodology used to qualify questionable data (Supplement III.2.5).

Note: This issue may not be confined to just the fuel characterization sub-project it is recommended that SNFP management evaluate this issue for project wide impacts and determine if corrective action should be taken at the project level.

44. The QARD requires the data reduction process to be described to permit another qualified individual to independentiy reproduce the results. In practice implementing procedures for analytical test methods, laboratory QAPPs provide such information. However, we have no written policy that says it (Supplement III.2.5B).

\section{SUPPLEMENT IV (FIELD SURVEY)}

This section is not applicable to SNFP Characterization since they are not involved with field survey activities.

\section{SUPPLEMENT V (CONTROL OF ELECTRONIC MANAGENENT OF DATA)}

This section is not applicable to SNFP Characterization since they are not managing their data through electronic means. 


\section{DISTRIBUTION SHEET}

\begin{tabular}{|c|c|c|c|c|c|}
\hline To & \multirow{2}{*}{\multicolumn{3}{|c|}{$\begin{array}{l}\text { From } \\
\text { Fuel Characterization } \\
\text { Project } / 2 T 650\end{array}$}} & \multicolumn{2}{|l|}{ Page 1 of 1} \\
\hline Distribution & & & & \multicolumn{2}{|c|}{ Date $06 / 11 / 97$} \\
\hline \multicolumn{4}{|l|}{ Project Title/Work Order } & \multicolumn{2}{|c|}{ EDT No. 620791} \\
\hline Qual ity Assurance Implementation & Plan for Spen & Nuclear & uel & \multicolumn{2}{|l|}{ ECN No. } \\
\hline Name & MSIN & $\begin{array}{l}\text { Text } \\
\text { With All } \\
\text { Attach. }\end{array}$ & Text Only & $\begin{array}{l}\text { Attach./ } \\
\text { Appendix } \\
\text { Only }\end{array}$ & $\begin{array}{c}\text { EDT/ECN } \\
\text { Only }\end{array}$ \\
\hline
\end{tabular}

U.S. Department of Energy,

Richland Operations office
P. G. Loscoe
S7-41
E. D. Sellers
S7-41
J. Shuen
S7-41
$X$
$X$
$X$

Fluor Daniel Hanford, Inc.

E. W. Gerber

Pacific Northwest National Laboratory

S. C. Marschman

R. C. Schrotke

DE\&S Hanford, Inc.

R. B. Baker

F. G. Hudson

L. A. Lawrence

P. G. LeRoy

R. P. Omberg

D. W. Smith Central Files (2)

SNF Project Files

DE\&S Northwest, Inc.

R3-11 X

$\begin{array}{ll}\text { P7-27 } & X \\ \text { P7-27 } & X\end{array}$

$\begin{array}{ll}\text { H0-40 } & X \\ \text { R3-11 } & X \\ \text { H0-40 } & X \\ \text { R3-15 } & X \\ \text { H0-40 } & X \\ \text { R3-15 } & X \\ \text { A3-88 } & X \\ \text { R3-11 } & X\end{array}$

M. J. Horhota

B1-13

$X$ 